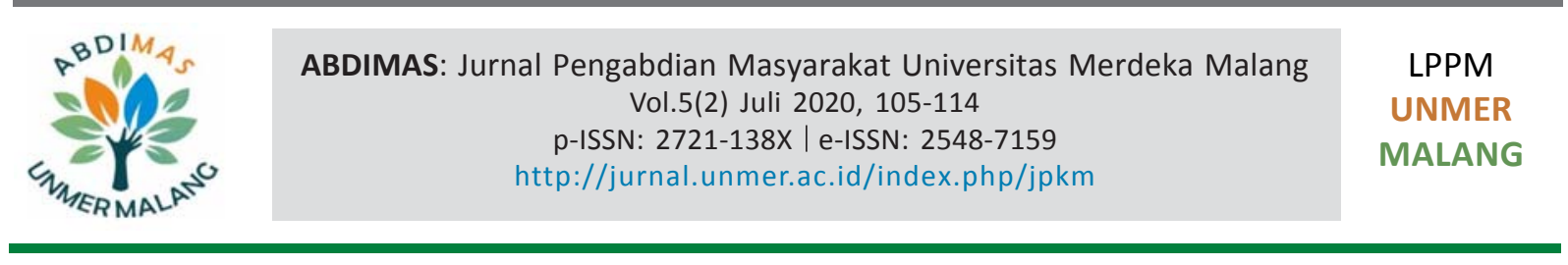

\title{
Penyuluhan Anti Narkoba Berbasis Spiritual Islam
}

\author{
Miftahul Ula, Amat Zuhri, Cintami Farmawati \\ Departemen Tasawuf dan Psikoterapi, Fakultas Ushuluddin, Adab dan Dakwah, Institut Agama Islam Negeri (IAIN) \\ Pekalongan \\ Jl. Kusumabangsa No. 9 Pekalongan, 51141, Indonesia
}

\section{ARTICLE INFO:}

Received: 2020-03-12 Revised: 2020-05-18 Accepted: 2020-06-24

\section{Keywords:}

counseling, drugs,

Islamic Spiritual

\section{ABSTRACT}

Islamic spiritual based anti-drugs counseling is a program of community empowerment activities in Sufism and psychotherapy that aims to increase teacher and community knowledge in preventing drug abuse among students in Batang District. Community empowerment activities through Islamic spiritual-based anti-drug counseling use discussion methods, lectures with audiovisual media, and role playing. The number of respondents was 20 teachers of guidance counseling and 10 community leaders. The results of the activity obtained an increase in the knowledge of guidance counseling teachers and community leaders from $13 \%$ to $83 \%$ in the good category. In addition, indicate the benefits of Islamic spiritual based anti-drug counseling on the knowledge of guidance counseling teachers and community leaders. Activities undertaken include: providing an understanding of the dangers of drug abuse; do role playing cure drug addicts through Islamic spirituality with Qolbu Brain Rejuvenation (ROQ) techniques, and conduct monitoring and evaluation. Islamic spiritual based anti-drugs counseling activities are considered effective and can be used as an alternative preventing drug abuse in Batang Regency.

(c) 2020 Published by University of Merdeka Malang. This is an open access article distributed under the CC BY-SA 4.0 license (https://creativecommons.org/licenses/by-sa/4.0/)

How to cite: Ula, M., Zuhri, A., \& Farmawati, C. (2020). Penyuluhan Anti Narkoba Berbasis Spiritual Islam. Abdimas: Jurnal Pengabdian Masyarakat Universitas Merdeka Malang, 5(2), 105-114.

https://doi.org/10.26905/abdimas.v5i2.4059

\section{PENDAHULUAN}

Narkoba di Indonesia menjadi hal yang mengkhawatirkan. Penyalahgunaan narkoba telah dijadikan bahaya laten yang sangat perlu diwaspadai. Narkoba sebagai zat yang sangat diperlukan untuk pengobatan dalam pelayanan kesehatan seringkali disalahgunakan tidak sesuai dengan standar pengobatan dan jika disertai peredaran narkoba secara gelap akan menimbulkan akibat yang sangat merugikan perorangan ataupun masyarakat, khususnya generasi muda bahkan dapat menimbulkan bahaya yang sangat besar bagi kehidupan dan nilai-nilai budaya bangsa yang pada akhirnya akan melemahkan ketahanan nasional. 
ABDIMAS: Jurnal Pengabdian Masyarakat Universitas Merdeka Malang

Volume 5, No 2, Juli 2020: 105-114

Narkoba dengan mudahnya dapat diperoleh bahkan yang sulit dideteksi adalah narkoba sudah dapat diracik sendiri (Mardani, 2008).

Penyalahgunaan narkoba dapat merusak perkembangan jiwa generasi muda baik bagi si pengguna maupun orang lain (Haerudin, Sadiah, \& Suparman, 2019; Ardiansyah \& Abdurahman, 2013). Di Amerika serikat, angka penyalahgunaan narkoba makin hari makin meningkat (Hendriyana, 2012). Data dari Europe School Survei Project on Alcohol and Drugs (ESPAD) dalam Survei Nasional BNN (2011) melaporkan 1 dari 5 pelajar di Republik Ceko, Perancis, Islandia, Swiss dan Inggris pernah menyalahgunakan narkoba dalam sebulan terakhir (19-22\%). Di Indonesia, hasil survei BNN (2018) menunjukkan prevalensi angka penyalahgunaan narkoba di kalangan pelajar di 13 ibu kota provinsi di Indonesia mencapai angkta 3,2 persen atau setara dengan 2,29 juta orang pada rentang usia 10-59 tahun.

Kepala Badan Narkotika Nasional Kabupaten (BNNK) Batang, Bapak Teguh Budi Santosa (2018) mengatakan bahwa peredaran dan penyalahgunaan narkoba kini semakin merajalela dan masuk ke semua segmen baik pelajar dan anak hingga ke pelosok desa. Adapun penyalahgunaan dan peredaran narkoba di kabupaten Batang yaitu berada di wilayah pantai utara karena letak geografisnya yang sangat memungkinkan terjadinya peredaran gelap narkoba, Teguh (2018) mengungkapkan bahwa pengguna narkoba didominasi 52 persen adalah kalangan pekerja, sedangkan 27 persen adalah pelajar dan sisanya adalah bukan pekerja, peredarannya pun kini sudah semakin luas hingga menyasar ke desa-desa dan juga ke sekolah tingkat dasar.

BNNK Batang saat ini mengalami kendala dalam kegiatan pencegahan narkoba apabila tidak mendapat dukungan dari semua komponen masyarakat. Kabupaten Batang khususnya Kecamatan Batang sebagai salah satu daerah yang rawan peredaran narkoba, perlu dilakukan program kegiatan bagaimana menciptakan kondisi masyarakat di daerah panturan ini menjadi daerah dengan generasi bangsa yang tanggap, unggul dan siap untuk melakukan pencegahan terhadap penyalahgunaan narkoba.

Spiritual Islam sebagai salah satu cara dalam mencegah bahaya narkoba penting untuk dilakukan. Spiritual dalam Islam melibatkan seluruh dimensi dalam diri manusia yaitu hati, akal dan fikiran. Sehingga dalam menjalankan kehidupan, manusia dapat melepaskan diri dari hal-hal yang menyangkut humanisme dan berpijak pada nilai-nilai ilahiah (segala sesuatu yang datangnya dari Allah). Penelitian Farmawati (2019), menyebutkan bahwa pendekatan sufistik atau spiritual Islam dapat menyembuhkan pecandu narkoba yang mencari narkoba. Selain itu, Noegroho et al. (2018), menjelaskan bahwa rehabilitasi spiritual mencintai keluarga dan teman, sholat, mengaji dan dzikir secara bersama dapat melawan dan mengurangi pecandu narkoba jenis sakau. Penelitian sejenis lainnya dari Permana (2018), Bakri \& Barmawi (2017), dan Irfangi (2015).

Kegiatan ini berupa pemberdayaan masyarakat melalui penyuluhan anti narkoba berbasis spiritual Islam. Tujuan dari kegiatan pengabdian masyarakat ini adalah untuk melakukan pemberdayaan kepada masyarakat dalam hal ini guru dan tokoh masyarakat di Kecamatan Batang Kabupaten Batang, sehingga masyarakat mampu melakukan pencegahan, mengenali tanda narkoba serta dapat melakukan pertolongan pertama dan bantuan terapi spiritual Islam pada pecandu narkoba yang ingin sembuh.

\section{METODE}

Metode pendekatan yang dilakukan dalam kegiatan pemberdayaan kepada masyakarat adalah memberikan informasi dan ketrampilan yang sederhana, murah dan aplikatif untuk diaplikasikan oleh 


\section{Penyuluhan Anti Narkoba Berbasis Spiritual Islam}

Miftahul Ula, Amat Zuhri, Cintami Farmawati

masyarakat (guru dan tokoh masyarakat) dalam melakukan pencegahan, mengenali dan melakukan pertolongan dan bantuan dengan pendekatan spiritual Islam bagi pecandu yang ingin sembuh. Metode pendekatan yang digunakan dalam pemberdayaan kepada masyakarat berbasis Program Studi Tasawuf dan Psikoterapi dengan tema penyuluhan anti narkoba berbasis spiritual Islam dapat dilihat pada beberapa tahapan dalam Gambar 1.

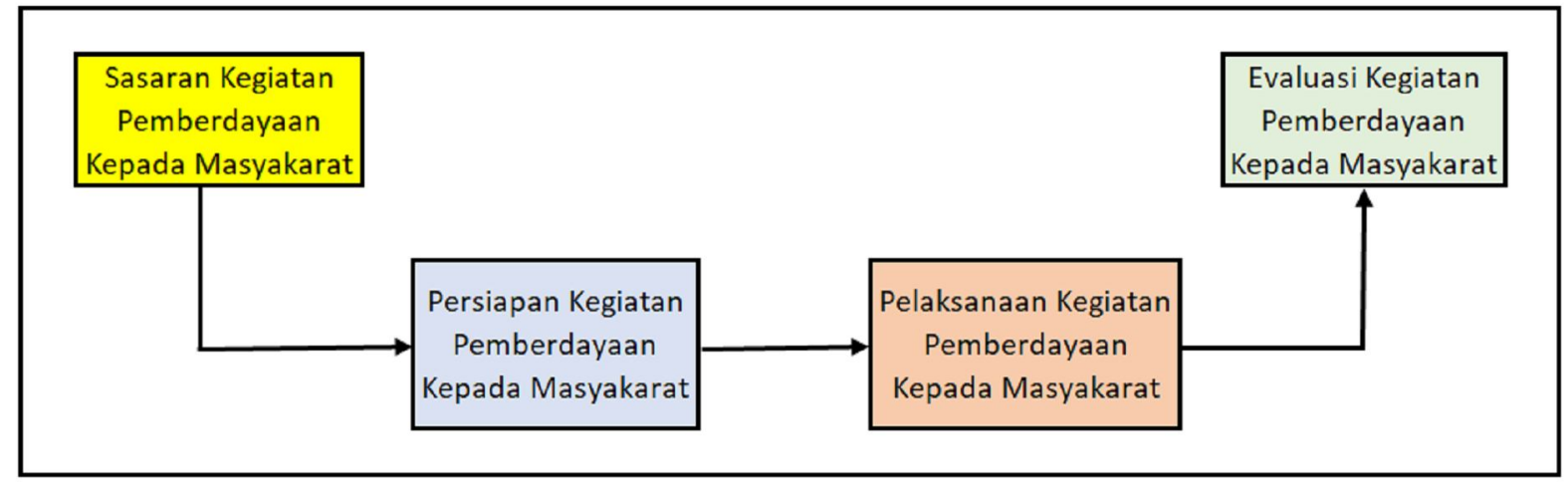

Gambar 1. Tahapan pemberdayaan kepada masyakarat berbasis Program Studi Tasawuf dan Psikoterapi dengan tema penyuluhan anti narkoba berbasis spiritual Islam

Sasaran kegiatan pemberdayaan kepada masyakarat berbasis Program Studi Tasawuf dan Psikoterapi adalah Guru Bimbingan Konseling (BK) dan Tokoh Masyarakat Kecamatan Batang Kabupaten Batang yang terdiri dari laki-laki dan perempuan dengan rentang usia 28-50 tahun, dimana banyak ditemukan kasus penggunaan narkoba adalah dari kalangan remaja sehingga Guru BK dan tokoh masyarakat sebagai garda terdepan memiliki peran yang penting dalam mencegah bahaya narkoba bagi peserta didik dan warga di Kecamatan Batang Kabupaten Batang.

Persiapan kegiatan pemberdayaan kepada masyakarat berbasis Program Studi Tasawuf dan Psikoterapi dilakukan dengan melakukan wawancara kepada pihak di Kecamatan Batang Kabupaten Batang dan mencatat data para Guru BK dan tokoh masyarakat di Kecamatan Batang Kabupaten Batang. Setelah memperoleh data untuk dijadikan peserta, berikutnya adalah menghubungi narasumber dan membuat undangan kegiatan pemberdayaan kepada masyarakat berbasis Program Studi Tasawuf dan Psikoterapi.

\section{Pelaksanaan Kegiatan}

Pelaksanaan kegiatan pemberdayaan masyarakat berbasis Program Studi Tasawuf dan Psikoterapi IAIN Pekalongan dilaksanakan dalam beberapa tahapan berikut.

Pengisian lembar pre-test oleh peserta pemberdayaan kepada masyakarat berbasis Program Studi Tasawuf dan Psikoterapi.

Penyuluhan anti narkoba berbasis spiritual Islam. Melalui penyuluhan ini, para peserta yang terdiri dari Guru BK dan Tokoh Masyarakat Kecamatan Batang diberikan informasi dan pengetahuan mengenai narkoba dan bahayanya, penanganan pada pecandu narkoba serta peran masyarakat dalam mencegah 
ABDIMAS: Jurnal Pengabdian Masyarakat Universitas Merdeka Malang

Volume 5, No 2, Juli 2020: 105-114

penyalahgunaan narkoba di Kecamatan Batang. Selain menggunakan instrumen ceramah, penyuluhan ini juga menggunakan media edukasi berupa video ( $f(\mathrm{l} m)$ tentang kondisi seseorang yang mengkonsumsi narkoba sehingga para peserta lebih mudah memahami pesan dan informasi yang diberikan. Metode ini difasilitasi dengan laptop, $L C D$, speaker, pengeras suara dan slide power point.

Metode diskusi dan tanya jawab. Metode ini bertujuan untuk membantu menjawab dan memecahkan permasalahan-permasalahan yang ditemukan selama proses kegiatan pemberdayaan masyarakat berlangsung, agar peserta yang telah diberikan penyuluhan menjadi lebih jelas dalam memahami materi yang telah disampaikan.

Pemutaran video. Untuk menarik perhatian para peserta saat penyuluhan, ada beberapa materi yang disampaikan dengan menggunakan media video, seperti materi bahaya narkoba dan penanganan pecandu narkoba dengan pendekatan spiritual Islam.

Demonstrasi penanganan pada pecandu narkoba. Pada akhir kegiatan penyuluhan dilakukan semacam demontrasi atau praktikum bersama dalam menangani pecandu narkoba disekitar kita dengan pendekatan spiritual Islam. Pendekatan Spiritual Islam yang disebut dengan Teknik Rejuvenasi Otak Qolbu $(R O Q)$, adalah yang tidak hanya mencegah namun juga membantu menyembuhkan pecandu narkoba. Kegiatan/materi ekstra ini diharapkan dapat dipraktikkan ketika menemui pecandu narkoba.

Pengisian lembar post-test oleh peserta pemberdayaan kepada masyakarat berbasis Program Studi Tasawuf dan Psikoterapi.

\section{Evaluasi Kegiatan}

Evaluasi dalam kegiatan pemberdayaan kepada masyakarat berbasis Program Studi Tasawuf dan Psikoterapi dilakukan melalui: (1) evaluasi hasil pre-test dan post-test peserta pemberdayaan kepada masyakarat berbasis Program Studi Tasawuf dan Psikoterapi. (2) Evaluasi hasil peningkatan pengetahuan mengenai bahaya narkoba dan pendekatan spiritual Islam setelah kegiatan pemberdayaan kepada masyakarat berbasis Program Studi Tasawuf dan Psikoterapi melalui kuesioner. (3) Evaluasi data hasil pemeriksaan kesehatan kegiatan pemberdayaan kepada masyakarat berbasis Program Studi Tasawuf dan Psikoterapi. (4) Analisis data yang dilakukan secara deskriptif melalui penyajian data menggunakan grafik dan tabel.

\section{HASIL DAN PEMBAHASAN \\ Hasil}

Kegiatan pemberdayaan masyarakat berbasis Program Studi Tasawuf dan Psikoterapi dilakukan atas dasar rendahnya kesadaran masyarakat akan bahaya narkoba di Kecamatan Batang Kabupaten Batang. Kegiatan pemberdayaan masyarakat berbasis Program Studi Tasawuf dan Psikoterapi dengan memberikan penyuluhan anti narkoba berbasis spiritual Islam kepada para guru Bimbingan Konseling dan tokoh masyarakat di Kecamatan Batang diharapkan dapat meningkatkan pengetahuan masyarakat terakait bahayanya narkoba di Kecamatan Batang. Adapun waktu pelaksanaan program kegiatan pemberdayaan masyarakat berbasis Program Studi Tasawuf dan Psikoterapi ditunjukkan pada Tabel 1. 


\section{Penyuluhan Anti Narkoba Berbasis Spiritual Islam}

Miftahul Ula, Amat Zuhri, Cintami Farmawati

Tabel 1. Jadwal pelaksanaan kegiatan pemberdayaan masyarakat berbasis

\begin{tabular}{llll}
\hline \multicolumn{1}{c}{ Waktu Kegiatan } & \multicolumn{1}{c}{ Uraian Kegiatan } & \multicolumn{1}{c}{$\begin{array}{c}\text { Tempat } \\
\text { Kegiatan }\end{array}$} & Durasi Kegiatan \\
\hline Kamis, & Pendaftaran dan Tes Kesehatan & Aula & 1 jam \\
Pukul 08.00-12.00 & $\begin{array}{l}\text { Penyuluhan Bahaya Narkoba kepada Guru BK dan } \\
\text { Tokoh Masyarakat di Kecamatan Batang }\end{array}$ & Kecamatan & $1 \mathrm{Jam} 30 \mathrm{Menit}$ \\
& $\begin{array}{l}\text { Pendekatan Spiritual Islam dalam menjauhkan diri dari } \\
\text { bahaya narkoba melalui ROQ }\end{array}$ & Kabupaten & 1 Jam 30 Menit \\
& Total Kegiatan & Batang & 4 Jam \\
\hline
\end{tabular}

Penyuluhan anti narkoba berbasis spiritual Islam dilaksanakan pada tanggal 27 September 2018 di Aula Kecamatan Batang Kabupaten Batang selama 4 jam yang meliputi pemberian materi tentang penyuluhan bahaya narkoba oleh Bapak Drs. Teguh Budi Susanto, MM (kepala BNN Kabupaten Batang) dan materi tentang pendekatan spiritual Islam dalam menjauhkan diri dari bahaya narkoba melalui ROQ (Rejuvenasi Otak Qolbu) oleh Bapak Dr. H. Sulaiman Al Kumayi, M.Ag (Ketua Jurusan Tasawuf dan Psikoterapi UIN Walisongo Semarang).

Sebelum pelaksanaan kegiatan, peserta yang terdiri dari para guru BK dan tokoh masyarakat ini diberikan soal pre-test tentang pengetahuan, bahaya narkoba dan penanganan pada pecandu narkoba. Pengetahuan ini diukur menggunakan instrumen pre-test. Tabel 2 adalah gambaran tingkat pengetahuan peserta sebelum diberikan penyuluhan anti narkoba berbasis spiritual Islam.

Tabel 2. Distribusi frekuensi pengetahuan peserta sebelum diberikan penyuluhan

\begin{tabular}{lrr}
\hline \multicolumn{1}{c}{ Pengetahuan } & Frekuensi & \% \\
\hline Kurang & 17 & 57 \\
Cukup & 9 & 30 \\
Baik & 4 & 13 \\
Total & 30 & 100 \\
\hline
\end{tabular}

Tabel 3. Distribusi Frekuensi Pengetahuan Peserta Sesudah Diberikan Penyuluhan

\begin{tabular}{lrr}
\hline \multicolumn{1}{c}{ Pengetahuan } & Frekuensi & \% \\
\hline Kurang & 0 & 0 \\
Cukup & 5 & 17 \\
Baik & 25 & 83 \\
Total & 30 & 100 \\
\hline
\end{tabular}

Dari Tabel 2 terlihat bahwa sebagian besar yaitu 17 peserta (57 persen) mempunyai pengetahuan kurang mengenai penyalahgunaan narkoba. Setelah pelaksanaan kegiatan selesai, peserta diberikan kembali kusioner post-test yang mengukur pengetahuan setelah diberikan penyuluhan anti narkoba berbasis spiritual Islam yang disajikan dalam Tabel 3.Dari Tabel 3 terlihat bahwa setelah diberikan materi secara intensif, jumlah peserta penyuluhan anti narkoba berbasis spiritual Islam yang mempunyai pengetahuan baik meningkat menjadi 25 (83 persen).

Hasil skor pengetahuan peserta penyuluhan anti narkoba berbasis spiritual Islam antara sebelum dan sesudah pelaksanaan penyuluhan dapat disajikan dalam Gambar 2 berikut ini: 
ABDIMAS: Jurnal Pengabdian Masyarakat Universitas Merdeka Malang

Volume 5, No 2, Juli 2020: 105-114

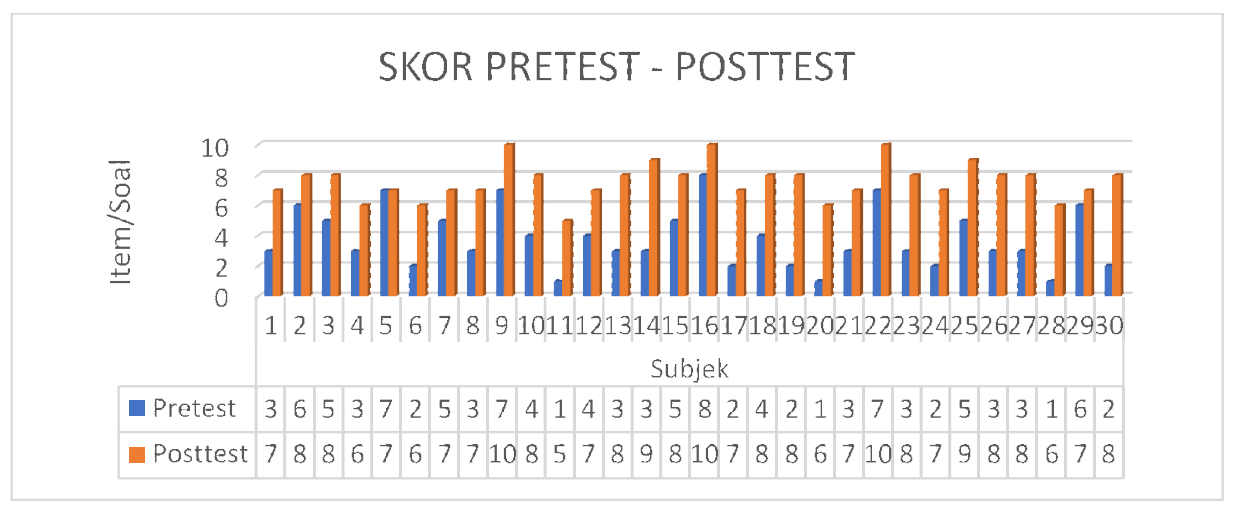

Gambar 2. Skor pre-test dan post-test peserta pengabdian kepada masyarakat

Berdasarkan data pada Gambar 2 dapat dilihat bahwa ada peningkatan pengetahuan peserta antara sebelum dan sesudah penyuluhan anti narkoba berbasis spiritual Islam. Setelah mengikuti penyuluhan anti narkoba berbasis spiritual Islam, peserta menjadi lebih memahami dan mengetahui bahaya narkoba dan penanganannya dengan spiritual Islam. Hasil wawancara dengan beberapa peserta menyampaikan bahwa kegiatan ini sangat menarik dan akan diimplementasikan dalam kehidupan sehari-hari untuk mencegah bahaya narkoba.

Kegiatan lain dalam penyuluhan anti narkoba berbasis spiritual Islam adalah pemeriksaan kesehatan secara umum dan pemeriksaan laboartorium tes narkoba. Hasil pemeriksaan tes narkoba digunakan untuk melihat kesehatan para peserta yang bebas dari narkoba untuk dipilih sebagai duta anti narkoba di Kecamatan Batang. Kegiatan penyuluhan anti narkoba berbasis spiritual Islam diakhiri dengan praktik teknik Rejuvenasi Otak Qolbu (ROQ) untuk menyembuhkan pecandu narkoba dipandu oleh narasumber bersama-sama dengan peserta penyuluhan dalam memotivasi peserta untuk turut serta dalam pencegahan penyalahgunaan narkoba di sekolah dan sekitar tempat tinggal masing-masing.

Dari pelaksanaan program pemberdayaan masyarakat berbasis Program Studi Tasawuf dan Psikoterapi terlihat para peserta sangat antusias mengikuti program penyuluhan anti narkoba berbasis spiritual Islam, sehingga para guru BK dan tokoh masyarakat mengetahui dan memahami akan bahaya jika mengkonsumsi narkoba dan bagaimana membantu menyembuhkan seseorang yang menjadi pecandu narkoba. Selanjutnya para Guru BK dan tokoh masyarakat dapat menyebarluaskan informasi tersebut di sekolah maupun masyarakat sebagai cara memutus penyebaran narkoba di Indonesia.
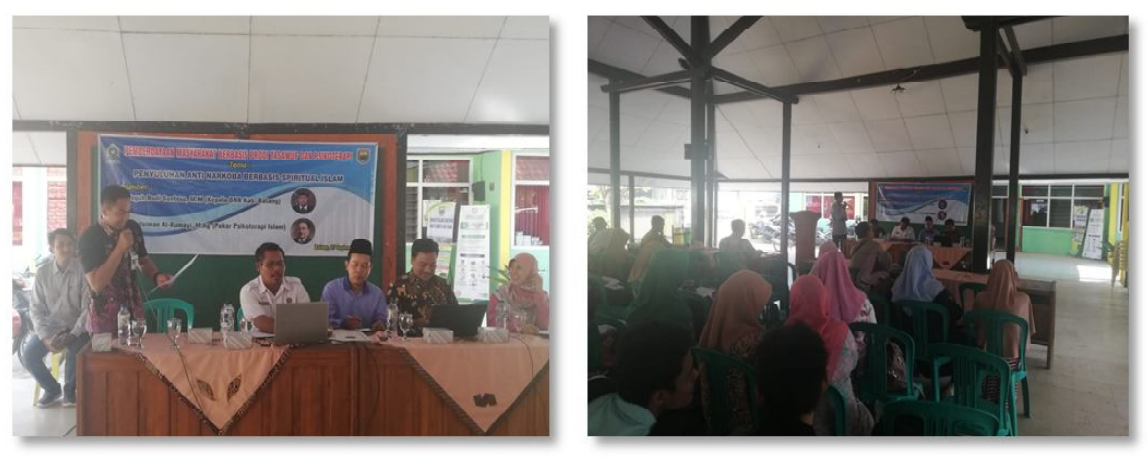

Gambar 3. Kegiatan penyuluhan anti narkoba berbasis spiritual Islam 


\section{Penyuluhan Anti Narkoba Berbasis Spiritual Islam}

Miftahul Ula, Amat Zuhri, Cintami Farmawati

Metode penyuluhan anti narkoba berbasis spiritual Islam adalah suatu cara atau kegiatan penyuluhan kepada masyarakat yang dilakukan didalam ruangan maupun diluar ruangan dalam rangka memberikan informasi, pengetahuan dan keterampilan kepada masyarakat yang dilakukan dengan cara pemberian materi kepada peserta oleh narasumber atau fasilitator. Narasumber atau fasilitator yang dimaksud salah satunya merupakan penyuluh atau pakar dalam bidang sesuai tema penyuluhan.

Tabel 4. Hasil kegiatan penyuluhan anti narkoba berbasis spiritual Islam

\begin{tabular}{cccl}
\hline $\begin{array}{c}\text { Skor } \\
\text { (A) }\end{array}$ & Jumlah Peserta (B) & $\begin{array}{c}\text { Total } \\
(\mathbf{A ~ x ~ B )}\end{array}$ & Kategori \\
\hline 4 & 24 & 96 & Sangat Suka \\
3 & 4 & 12 & Suka \\
2 & 2 & 4 & Tidak Suka \\
1 & 0 & 0 & Sangat Tidak Suka \\
Jumlah & 30 & 118 & \\
\hline
\end{tabular}

Dari Tabel 4 dapat dikatakan bahwa kegiatan penyuluhan anti narkoba berbasis spiritual Islam yang sangat disukai oleh peserta sebanyak 24 orang dari total nilai 30, dengan nilai 96, dan yang hanya disukai hanya sebanyak 4 orang dengan nilai 12 . Hal ini menunjukkan bahwa sangat sedikit masyarakat tidak menyukai kegiatan penyuluhan anti narkoba berbasis spiritual Islam yaitu sebanyak 2 orang dengan nilai 4. Dengan demikian bahwa secara keseluruhan peserta sangat menyukai kegiatan penyuluhan anti narkoba berbasis spiritual Islam dengan index persentase 80 persen dan termasuk dalam kategori sangat tinggi. Hal ini dapat dikatakan bahwa peserta telah merasakan manfaat dari kegiatan penyuluhan anti narkoba berbasis spiritual Islam yang dilakukan oleh sehingga apa yang disampaikan narasumber kepada peserta pada umumnya dapat diserap oleh peserta dengan baik serta dapat menyebarkan materi penyuluhan kepada masyarakat luas dan menjadi duta anti narkoba bagi diri dan orang lain.

\section{Pembahasan}

Berdasarkan hasil kegiatan penyuluhan anti narkoba berbasis spiritual Islam terbukti bahwa pelaksanaan kegiatan tersebut merupakan sarana untuk belajar bersama tentang bahaya narkoba dan penanganan narkoba dalam bentuk tatap muka secara kelompok yang bertujuan untuk meningkatkan pengetahuan para guru dan tokoh masyarakat mengenai macam-macam narkoba, proses penyebaran dan tanda bahaya kecanduan narkoba serta penanganan pertama pada pecandu narkoba dengan ROQ. Hasil menunjukkan bahwa ada peningkatan pengetahuan peserta antara sebelum dan sesudah penyuluhan anti narkoba berbasis spiritual Islam. Sesuai dengan penelitian Mustafa et al. (2019) menjelaskan bahwa bentuk pengabdian berupa sosialisasi narkoba efektif untuk memberikan pengetahuan mengenai bahaya narkoba.

Perencanaan kegiatan dilakukan dengan tahapan yaitu melakukan pendekatan dengan Kepala Kecamatan Batang dan Kepala BNN Kabupaten Batang untuk merencanakan kegiatan pemberdayaan masyarakat berbasis Prodi Tasawuf dan Psikoterapi. Selanjutnya mengirim surat permohonan ijin pemberdayaan masyarakat ke BAPPEDA, kepala BNNK Batang, dan Kepala Kecamatan Batang. Setelah mendapatkan izin dari BAPPEDA, kepala BNNK Batang, dan Kepala Kecamatan Batang kemudian melakukan 
ABDIMAS: Jurnal Pengabdian Masyarakat Universitas Merdeka Malang

Volume 5, No 2, Juli 2020: 105-114

pendekatan kepada Guru BK dan tokoh masyarakat yang beradaa di Kecamatan Batang sebagai penanggung jawab program penyuhuhan anti narkoba berbasis spiritual Islam di Kecamatan Batang.

Tahap berikutnya melakukan identifikasi permasalahan bahwa di Kecamatan Batang merupakan salah satu kecamatan yang rawan terhadap penyalahgunaan narkoba dengan melakukan wawancara pada Guru BK, Tokoh Masyarakat, Kepala Desa, Kepala BNNK Batang dan para siswa melalui pertemuan untuk dilakukan pemberian penyuluhan sesuai dengan kebutuhan dalam mencegah penyalahgunaan narkoba di Kecamatan Batang.

Penyusunan program kegiatan penyuluhan anti narkoba berbasis spiritual Islam bagi Guru BK dan tokoh masyarakat kecamatan Batang, meliputi pemberian Pendidikan Anti Narkoba mengenai macammacam narkoba dan bahaya penyalahgunaan narkoba dan penanganan secara spiritual Islam pada pecandu narkoba. Pemeriksaan kesehatan meliputi pemeriksaan tensi darah, berat badan, tinggi badan, tes narkoba dengan urin dan praktik spiritual Islam untuk pecandu narkoba yang ingin sembuh.

Penggunaan media alat bantu penyuluhan dan metode penyuluhan yang variatif mampu meningkatkan pemahaman peserta terhadap informasi dan materi yang diberikan serta memberikan motivasi pada peserta untuk selalu mengikuti penyuluhan sampai akhir. Hal ini sesuai dengan penelitian Kapti (2013) bahwa penggunaan media audio visual mempunyai pengaruh terhadap peningkatan pengetahuan dan sikap.

Tahap yang terakhir yaitu melakukan evaluasi. Evaluasi dilakukan untuk melihat sejauh mana manfaat dari kegiatan ini untuk peserta dan lainnya. Evaluasi dilakukan sebelum dan sesudah kegiatan penyuluhan dengan memberikan lembar evaluasi kepada peserta untuk diisi.

Hasil dari kegiatan penyuluhan anti narkoba berbasis spiritual Islam menjadi rujukan bagi BNN Kabupaten Batang dalam menentukan duta anti narkoba di Kabupaten Batang. Pada tangal 26 April 2018, BNNK Batang telah mengukuhkan 150 penggiat anti narkoba, yang terdiri dari penggiat dikalangan masyarakat ada 15 orang, Pemerintahan 30 orang dan di kalangan pelajar 105 orang. "Untuk kalangan pemerintahan dan masyarakat berasal dari TNI/POIRI, Komunitas, dan lainnya, sedangkan penggiat dikalangan pelajar terdiri dari Guru dan kepala sekolah,". Teguh menjelaskan bahwa tugas dari penggiat adalah mensosialisasikan bahaya narkoba sehingga mereka akan dibekali keahlian motivasi dan public speaking. Selain itu, para penggiat juga harus melaporkan, menangkap dan menyerahkan kepada pihak kepolisian jika menemukan pengedar. Kemudian menyusun rencana aksi yang berisi aksi mereka ketika memberantas narkoba. Sehingga para penggiat anti narkoba harus membentengi masyarakat terhadap narkoba, yang harapannya bisa menekan angka penyalahgunaan narkoba (Teguh, 2018).

\section{SIMPULAN DAN SARAN}

\section{Simpulan}

Pelaksanaan kegiatan pemberdayaan masyarakat berbasis Program Studi Tasawuf dan Psikoterapi berupa kegiatan penyuluhan anti narkoba berbasis spiritual Islam berjalan dengan sangat baik. Para peserta merasa antusias dan senang dalam mengikuti kegiatan ini, hal ini dikarenakan belum ada penyuluhan anti narkoba berbasis spiritual Islam di Kecamatan Batang dan masih membutuhkan bimbingan mengenai bahaya dan penanganan penyalahgunaan narkoba. Sehingga dengan adanya penyuluhan ini, diharapkan mampu memberikan bekal ke Guru BK dan tokoh masyarakat untuk terhindar dari bahaya narkoba. Kegiatan 


\section{Penyuluhan Anti Narkoba Berbasis Spiritual Islam}

Miftahul Ula, Amat Zuhri, Cintami Farmawati

Penyuluhan Anti Narkoba berbasis Spiritual Islam di Kecamatan Batang dari 30 peserta dan dapat dilaksanakan dengan target 30 pula, ada peningkatan pengetahuan peserta sesudah penyuluhan anti narkoba berbasis spiritual Islam sebanyak $83 \%$ dalam kategori baik.

\section{Saran}

Pemberdayaan masyarakat berbasis prodi Tasawuf dan Psikoterapi melalui penyuluhan anti narkoba berbasis spiritual Islam meningkatkan pengetahuan para peserta kegiatan. Selanjutnya, kegiatan pemberdayaan masyarakat berbasis prodi Tasawuf dan Psikoterapi diharapkan dapat melibatkan komunitas yang lebih banyak, wilayah yang lebih luas dan diharapkan dapat memberikan pemberdayaan kasus yang banyak terjadi di masyarakat.

\section{UCAPAN TERIMA KASIH}

Kegiatan pengabdian kepada masyarakat ini didanai oleh Lembaga Penelitian dan Pengabdian Kepada Masyarakat Institut Agama Islam Negeri Pekalongan.

\section{DAFTAR PUSTAKA}

Ardiansyah, Y., \& Abdurahman, L. (2013). Penyuluhan pencegahan bahaya narkoba terhadap anakanak usia dini. Jurnal Inovasi dan Kewirausahaan, 2(2), 104-108.

Badan Narkotika Nasional. (2011). Perkembangan Penyalahgunaan dan Peredaran Gelap Narkoba pada Kelompok Pelajar dan Mahasiswa di 16 Provinsi di Indonesia. Jakarta: Ringkasan Eksekutif BNN.

Badan Narkotika Nasional. (2018). Jurnal Data Pencegahan dan Pemberantasan Penyalahgunaan dan Peredaran Gelap Narkoba. Jakarta: BNN.

Bakri, N., \& Barmawi. (2017). Efektifitas rehabilitasi pecandu narkotika melalui terapi Islami di Badan Narkotika Nasional (BNN) Banda Aceh. Jurnal Psikoislamedia, 2(1), 86-95. https://doi.org/10.22373/psikoislamedia.v2i1.1827

Farmawati, C. (2018). Sufistic therapy with Spiritual Emotional Freedom Technique (SEFT) Method for healing the behavior of drugs addict. Jurnal Theologia, 30(1), 107-126. https://doi.org/10.21580/teo.2019.30.1.3393

Haerudin, Sadiah, T. L., Suparman, T. (2019). Penyuluhan bahaya narkoba terhadap anak-anak SD. Jurnal Buana Pengabdian, 1(1), 37-47. https://doi.org/10.36805/jurnalbuanapengabdian.v1i1.578

Hendriyana, A., (2012). Upaya peningkatan dan pengetahuan, sikap dan perilaku pada Siswa SMUN 2 Krakatau Steel mengenai pencegahan penyalahgunaan narkoba dengan Metode Diskusi Kelompok Kecil. Tesis. Yogyakarta: Universitas Gajah Mada. Survei Nasional.

Irfangi, M. (2015. Implementasi pendekatan religius dalam rehabilitasi korban penyalahgunaan narkoba di Rumah Sakit Khusus Jiwa H. Mustajabah Purbalingga. Jurnal Kependidikan, 3(2), 70-88. https://doi.org/10.24090/jk.v3i2.900

Kapti, R. E., Rustina, Y., \& Widyatuti, W. (2013). Efektifitas audiovisual sebagai media penyuluhan kesehatan terhadap peningkatan pengetahuan dan sikap ibu dalam tata laksana balita dengan diare di dua rumah sakit Kota Malang. Jurnal Ilmu Keperawatan, 1(1), 53-60. 
ABDIMAS: Jurnal Pengabdian Masyarakat Universitas Merdeka Malang

Volume 5, No 2, Juli 2020: 105-114

Mardani. (2008). Penyalahgunaan Narkoba dalam Perspektif Hukum Islam dan Hukum Pidana Nasional. Jakarta: Raja Grafindo Persada.

Mustafa, I. R., Abdillah, M. B., Winata, N. R., \& Pratama, R. (2019). Edukasi "Gerakan Siswa Anti Narkoba" (GESWANA) Era Disrupsi 4.0 di SMP Wahid Hasyim Malang. Dinamisia-Jurnal Pengabdian Kepada Masyarakat, 3(2), 189-197. https://doi.org/10.31849/dinamisia.v3i2.3214

Noegroho, A., Sulaiman, A. I., Suswanto, B., \& Suryanto. (2018). Pendekatan spiritual dan herbal sebagai alternatif rehabilitasi non medis bagi pecandu narkoba. Al Izzah: Jurnal Hasil-Hasil Penelitian, 13(2), 143-158. https://doi.org/10.31332/ai.v13i2.983

Permana, D. (2018). Peran spiritualitas dalam meningkatkan resiliensi pada residen narkoba. Syifa AlQulub, 2(2): 21-32. https://doi.org/10.15575/saq.v2i2.2972

Teguh, B. S. (2018). Tekan Penyalahgunaan Narkoba, BNN Kabupaten Batang Kerahkan 150 Penggiat Anti narkoba. http://jateng.tribunnews.com/2018/04/26/tekan-penyalahgunaan-narkoba-bnnkabupaten-batang-kerahkan-150-penggiat-antinarkoba. Diakses pada 2 Oktober 2018. 